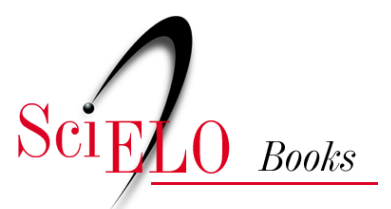

\title{
1. Sobre as relações sociais capitalistas
}

\author{
Miriam Limoeiro Cardoso
}

\section{SciELO Books / SciELO Livros / SciELO Libros}

CASDOSO, M.L. Sobre as relações sociais capitalistas. In: LIMA, J.C.F., and NEVES, L.M.W., org. Fundamentos da educação escolar do Brasil contemporâneo [online]. Rio de Janeiro: Editora FIOCRUZ, 2006, pp. 25-66. ISBN: 978-85-7541-612-9. Available from: doi: 10.7476/9788575416129.0003. Also available in ePUB from: http://books.scielo.org/id/j5cv4/epub/lima-9788575416129.epub.

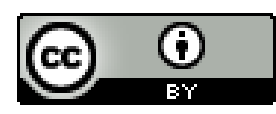

All the contents of this work, except where otherwise noted, is licensed under a Creative Commons Attribution $\underline{4.0 \text { International license. }}$

Todo o conteúdo deste trabalho, exceto quando houver ressalva, é publicado sob a licença Creative Commons Atribição 4.0. 


\title{
I. Sobre as Relações Sociais Capitalistas
}

\author{
Miriam Limoeiro Cardoso
}

Tout ce qui était solide, bien établi, se volatilise, tout ce qui était sacré se trouve profané, et à la fin les hommes sont forcés de considérer d'un cil détrompé la place qu'ils tiennent dans la vie, et leurs rapports mutuels.

Karl Marx, 1848 (in Marx, 1965:164-165)

The nature of our epoch is multiplicity and indeterminacy. It can only rest on das Gleitende [the moving, the slipping, the sliding], and is aware that what other generations believed to be firm is in fact das Gleitende.

Hugo von Hofmannsthal, 1905 (apud Callinicos, 1989:12)

Il existe un tableau de Klee qui s'intitule "Angelus Novus". Il représente un ange qui semble sur le point de s'éloigner de quelque chose qu'il fixe du regard. Ses yeux sont écarquillés, sa bouche ouverte, ses ailes déployées. C'est à cela que doit ressembler l'Ange de l'Histoire. Son visage est tourné vers le passé. Là où nous apparaît une chaîne d'événements, il ne voit, lui, qu'une seule et unique catastrophe, qui sans cesse amoncelle ruines sur ruines et les précipite à ses pieds. Il voudrait bien s'attarder, réveiller les morts et rassembler ce qui a été démembré. Mais du paradis souffle une tempête qui s'est prise dans ses ailes, si violemment que l'ange ne peut plus les refermer. Cette tempête le pousse irrésistiblement vers l'avenir auquel il tourne le dos, tandis que le monceau de ruines devant lui s'élève jusqu'au ciel. Cette tempête est ce que nous appelons le progrès.

Walter Benjamin, 1940 (in Benjamin, 2000:434) 


\section{Capitalismo, Modernidade, Pós-Modernidade}

O conceito de modernidade expressa a convicção de que o futuro chegou (Habermas, 1987:7). A idéia de modernidade se ligou indissociavelmente à concepção de progresso histórico. Refere-se a uma época que se volta para o futuro e pretende fundar a própria legitimidade na crença relacionada à expectativa de melhoria futura infinita, uma era 'nova', que causa espanto porque transforma de alto a baixo tudo o que havia antes, mas além disso ela mesma promove uma transformação incessante e vertiginosa. Daí sua caracterização como efêmera, fugidia, contingente (Baudelaire), das Gleitende (Hofmannsthal). Mas constrói destruindo.

Curiosamente, essa ordem nova em que 'tudo que é sólido desmancha no ar' pensa tudo o mais em relação a ela, todo o passado como seus antecedentes, e o futuro como sendo apenas o seu futuro. Explica-se a nomenclatura: modernidade e moderno como idênticos a atual, forma presente de algo há muito antecipado; e presente que se prolonga indefinidamente num futuro pensado tão-somente como desdobramento ou desenvolvimento daquilo que é. Assim, a época da historicidade radical naturaliza a história na própria concepção que cria de si mesma. Marx adverte:

fault il bien distinguer les déterminations qui valent pour la production en général, afin que l'unité (...) ne fasse pas oublier la différence essentielle. C'est de cet oubli que découle, par exemple, toute la sagesse des économistes modernes qui prétendent prouver l'éternité et l'harmonie des rapports sociaux existant actuellement. (Marx, 1957:151)

Se a admissão da historicidade dessa sociedade implica a sua constituição num momento histórico dado, implica também a sua transitoriedade - ela não é perene, não é para sempre. 'A' sociedade é somente uma abstração. A concepção de que essa é uma determinada ordem social, histórica, considera-a constituída num dado tempo histórico, por forças sociais, históricas, em ascensão (no caso, burguesas), em luta contra forças sociais, históricas, que sustentavam a formação social anterior. Isso não impede que, em geral, a literatura que trata o capitalismo como sociedade moderna se empenhe em defini-la na 'sua especificidade', diferenciada das sociedades anteriores a ela, mas considerandoas como pré-capitalistas, sob diversas denominações.

A modernidade se afirma não como uma ordem, mas como 'a' ordem. Zygmunt Bauman alerta: 
ordem e caos são gêmeos modernos. Foram concebidos em meio à ruptura e ao colapso do mundo ordenado de modo divino, que não conhecia a necessidade nem o acaso, um mundo que apenas era, sem pensar jamais em como ser. (...) A descoberta de que a ordem não era natural já foi a descoberta da ordem como tal. (Bauman, 1999:12, 14)

Há uma grande clivagem quanto à aproximação pela via teórica - que inclui uma importante dimensão política - do que seja a sociedade atual: considerá-la como sociedade 'moderna' ou como sociedade 'do capital', sociedade capitalista.

A modernidade pode ser concebida como uma proposta de realização do projeto iluminista, implantando uma sociedade racional sob a égide da ciência, que assim ganha ares de senhora da Razão, e que nessa qualidade é chamada a controlar a natureza e também, por que não, o homem. Nesse caso, os dois pólos da clivagem não se afastam; pelo contrário, têm muito em comum. No entanto, depois de tantos genocídios, dos horrores do nazismo e do stalinismo, de Hiroshima e Nagasaki, do atual estado permanente de guerra, impõe-se fazer a crítica, consistente e profunda, da crença na Razão como dominadora do mundo natural e social e como iluminadora por si mesma da consciência dos homens. São exatamente essas as experiências fracassadas que a Teoria Crítica denuncia e que o pós-modernismo também iria denunciar. Em nome da Razão muitas formas de opressão foram forjadas, e assim a modernidade, de expressão de uma força de libertação, mostrou-se uma fonte de subjugação e de repressão.

Bauman coloca bem, o holocausto não é um episódio histórico que deva ser considerado como único, ou porque teria sido especificamente judeu ou especificamente alemão, ou porque teria sido uma erupção específica de forças pré-modernas - bárbaras, irracionais.

A visão nazista de uma sociedade harmoniosa, ordeira, sem desvios, extraía sua legitimidade e atração dessas visões e crenças já firmemente arraigadas na mente do público ao longo do século e meio de história pós-iluminista, repleta de propaganda cientificista e exibição visual da assombrosa potência da tecnologia moderna. (Bauman, 1999:38)

Como estudos críticos do pós-colonialismo podem sugerir, a experiência nazista talvez revele ainda mais fundo o 'espírito do capitalismo' ou a razão do capital, bem distinta da Razão Iluminista. Aimé Césaire diz: 
Oui, il vaudrait la peine de révéler au très distingué, très humaniste, très chrétien bourgeois du XX $\mathrm{XX}^{\mathrm{e}}$ siècle (...) qu'au fond, ce qu'il pardonne pas à Hitler, c'est ne pas l'humiliation de l'homme en soi, c'est le crime contre l'homme blanc, c'est l'humiliation de l'homme blanc, et d'avoir appliqué à l'Europe des procédés colonialistes dont ne révélaient jusqu'ici que les Arabes d'Algerie, les coolies de l'Inde, et les nègres d'Afrique. (Césaire, 1995:12, apud Mezzadra \& Rahola, 2006).

Robin Kelley entende que essa formulação descobre que "the real 'taboo' shuttered by nazi-fascism consists in the very fact of applying directly to white European subjects what was conceivable only in the colonial world" (Kelley, 2002:175, apud Mezzadra \& Rahola, 2006).

O que Max Weber apontou como a racionalização crescente e o desencantamento do mundo - no seu entender características da sociedade capitalista moderna - produziu de fato uma ordem social que é racional para o capital. A racionalidade própria do capitalismo se fundamenta em novas formas de exploração e de dominação e na esperança de que a expansão do capital signifique progresso e melhoria para todos. Walter Benjamin entendia que a tarefa cognitiva mais urgente era desmantelar o mito da história como progresso. Na Dialética do Esclarecimento, Max Horkheimer e Theodor Adorno (1985) se debruçam sobre aquela visão racionalista, idealista e progressista da história e formulam a negação crítica dessa suposta racionalidade prometida pelo Iluminismo e que podia ser experimentada como opressão, conformismo, sofrimento, destruição, nos tempos sombrios da guerra e do fascismo.

Para ser capaz de fazer essa crítica é preciso, antes de mais nada, situar historicamente a razão, buscando encontrar seus vínculos com o poder constituído ou em constituição - dos quais resulta a sua própria formação - e com as classes e os segmentos sociais que impulsionam ou sustentam esse poder.

Dizer de uma determinada sociedade que ela é moderna é considerá-la como a forma social recente. Tal designação supõe uma concepção cronológica de história, concepção que justapõe um 'antigo', anterior, e um 'moderno', atual, com a possibilidade lógica formal de estabelecer momentos intermediários. Como o tempo continua correndo, cabe também especificar um 'mais moderno' em relação ao 'moderno', chamado contemporâneo, por exemplo. Nem sempre, porém, a designação 'contemporâneo' é a mais conveniente, porque nesse tipo de pensamento não há diferença de fundamento entre os diferentes 'momentos' históricos. Como ele opera uma espécie de naturalização da 
história, a singularidade atual é desdobrada em fases ou estágios anteriores de um mesmo processo de desenvolvimento. Neste sentido, o 'contemporâneo' apenas 'atualiza' o 'moderno'. Mas quando a sociedade instalada no Ocidente nos séculos XVIII-XIX foi pensada como sociedade industrial ou moderna, pensamento que foi reforçado no século XX com a chamada 'teoria da modernização', essa caracterização da sociedade como industrial ou moderna pretendia substituir a caracterização histórica dessa mesma sociedade nomeada 'capitalista'. Não se trata apenas de nomes diferentes ou de filigranas de diferenças conceituais entre autores; existe aí uma dimensão profunda que é política, até porque a questão da historicidade diferencial do capitalismo envolve Marx, o(s) marxismo(s), os movimentos socialistas e as sociedades ditas socialistas.

Fredric Jameson fala de uma reinvenção do conceito de modernidade em plena pós-modernidade e supõe que isso faz parte de uma "guerra política discursiva", em que os adversários do livre mercado são classificados por meio da categoria negativa de não-modernos, privados de modernidade (Jameson, 2002:9-10). Encontra nesse tipo de procedimento uma incoerência conceitual e filosófica: são tidos como não-modernos porque ainda são modernistas; é o próprio modernismo que é apreendido como não-moderno. No entanto, a 'modernidade', conforme o novo sentido positivo atribuído ao termo, é tida como 'boa' porque... é pós-moderna!

Embora nem sempre isso seja admitido explicitamente como motivo, para a sociedade capitalista há uma explicação, que pode conter ambivalências ou contradições, mas que além de densidade teórica alcançou enorme densidade política. As teorias sociais pós-modernas consideram o capitalismo como passado, como 'fase' já superada de uma história em processo sempre em busca do novo (aliás, nada mais próprio do espírito da modernidade do que essa incessante busca e incorporação de 'novidade'), o que facilita sem dúvida considerar como também ultrapassados Marx e o(s) marxismo(s). Desse ponto de vista, é mais conveniente nomear esse 'novo' como 'pós' (pós-capitalista, pósmoderno) do que apenas como 'contemporâneo'. Certamente o pós-moderno é muito mais do que uma estratégia teórico-ideológica como essa, porque é marcado profunda e positivamente pela crítica contundente ao Iluminismo, mas certamente também contém um sentido político importante de superação de Marx e do(s) marxismo(s).

Muitos afirmam que já estamos no pós-capitalismo. Sem dúvida, há transformações importantes que ocorrem na década de 1970, acompanhando mu- 
danças tecnológicas significativas e novos padrões organizacionais na produção e na gestão capitalista. Nesse contexto, não faltaram os anunciadores do 'fim' e, conseqüentemente, dos 'pós', exemplarmente representados por Francis Fukuyama e seu 'fim da história' (Cardoso, 1999) ou Daniel Bell e sua 'sociedade pós-industrial'. De fato, essas teorias abrangem as generalizações sociológicas que anunciam com entusiasmo já se ter implantado um tipo de sociedade completamente novo, designado também como sociedade de consumo, sociedade da informação, sociedade do conhecimento etc. Fredric Jameson supõe que essas teorias cumprem uma "missão ideológica", que considera óbvia: "demonstrar, para seu próprio alívio, que a nova formação social em questão não obedece mais às leis do capitalismo clássico" (Jameson, 1991:3). Para este autor, a 'tarefa' ideológica fundamental do conceito de pós-moderno é coordenar novas formas de prática e de hábitos sociais e mentais com as novas formas de produção e organização econômica provocadas pela modificação recente da divisão global do trabalho - ou seja, proclamar que a sociedade já não é mais capitalista. Como o capitalismo não acabou, ${ }^{1}$ sua morte anunciada possui uma dimensão ideológica à qual Jameson se refere como missão ou tarefa a cumprir. Está certo pelo menos nos casos em que produções cujo conteúdo é ideológico são feitas por cientistas que recorrem à autoridade científica para produzir, veicular e fazer circular ideologia. Talvez Jameson generalize em demasia. O que, porém, de modo algum pode servir de argumento para desconsiderar a indicação - que é pertinente e correta - da dimensão ideológica muito eficaz que acompanha aquelas teorias ou faz parte delas.

Por outro lado, também não têm faltado contribuições relevantes analisando as características e as implicações das mudanças recentes como internas ao capitalismo, algumas considerando, aí sim, a existência de crise no capitalismo ou do capitalismo.

\section{Modernização, Capitalismo Dependente}

Para enfrentar o problema de uma nova expansão capitalista e promover na parte pobre e subordinada do mundo mudanças adequadas a essa expansão, surgem as teorias da modernização, que alegam ter validade geral, abrangendo todas as sociedades, em todos os tempos. Essa proposta de mudança é pensada no interior da concepção norte-americana de Guerra Fria, que as próprias teorias da modernização ajudaram a consolidar. 
By defining a singular path of progressive change, the concept of modernization simplified the complicated world-historical problems of decolonization and industrialization, helping to guide American economic aid and military intervention in post-colonial regions. (Gilman, 2003:3) ${ }^{2}$

Do modo como a teoria da modernização organiza o mundo, as sociedades em geral são distribuídas dentro de uma mesma escala, na qual é possível distinguir um padrão ou estágio 'primitivo'3 ou 'tradicional' e um outro 'moderno', com variados ou variáveis estados intermediários, cada um dos quais identificado por possuir diferencialmente atributos que são definidos pela própria teoria. A modernização é apresentada como o processo de passagem de um padrão a outro, passagem no entanto não explicada pela teoria.

A modernização se refere à mudança apenas numa certa direção, a direção desejada, até porque "there were no controversial choices to make, since the goal was already given” (Therborn, 2001:57). Mesclando profundamente teoria e ideologia, a modernização elabora, justifica e ela mesma legitima a própria elaboração. Latham (2000:60) a qualifica como uma combinação de visão missionária e controle imperial. ${ }^{4}$

As teorias da modernização são produzidas precisamente no momento histórico em que uma nova hegemonia está se constituindo no desenvolvimento do capitalismo. Portanto, são muito convenientes teórica e politicamente. A partir da Segunda Guerra Mundial e no imediato pós-guerra, o capitalismo começava uma nova expansão, e a economia dos Estados Unidos, fortalecida durante a guerra, colocava em pauta a necessidade de expandir os mercados e aumentar um certo tipo de produção na Ásia, na América Latina e na África (Cardoso, 2005b). É nesse exato momento que as teorias da modernização e do desenvolvimento, conjugadas, são oferecidas como fundamentação das políticas desenvolvimentistas, as quais são apresentadas como garantia para a nova expansão capitalista voltada para o Terceiro Mundo e, no mesmo movimento, como barragem contra uma temida expansão comunista.

No Brasil, a modernização tem sido a perspectiva dominante no cenário político, pelo menos a partir de Juscelino Kubitschek, com as exceções dos governos Jânio Quadros e João Goulart. A ditadura militar instalada em 1964 retomou e radicalizou a política de caráter modernizador que já havia caracterizado o governo JK e desde então essa perspectiva vem orientando, sem qualquer interrupção, a ação do governo central no Brasil, ela própria se adaptando aos novos formatos que a modernização tem assumido. Na política brasileira, 
Juscelino Kubitschek é exemplar quanto à modernização desenvolvimentista e Fernando Henrique Cardoso quanto à modernização neoliberal (Cardoso, 2005c).

Muitos consideram a modernização como uma perspectiva datada, por seu alcance limitado a um período que já estaria encerrado. No entanto, o que se tem chamado de globalização consiste na retomada da 'teorização' da modernização, adaptando-a às formas atuais da expansão capitalista. "Indeed it [modernization theory] created the rationale for economic aid. The debate is still far from dead. Modernization theory resurfaces in current debates about modernity and post-modernity and in the neo-liberal agenda" (Dickson, 1997:36). Fala-se mesmo em teoria da modernização neoliberal (Kieley, 1995). A questão em torno da modernização continua atual e relevante.

A modernização tem recebido críticas severas, mas tem funcionado de fato como uma ideologia muito eficaz, como que impermeável à crítica. Entranhou-se nas concepções usuais, aceitas de maneira geral. No Brasil, desde JK tornou-se senso comum querer ser 'moderno', vale dizer, ser 'desenvolvido', equiparar-se ao 'Primeiro Mundo'. A ideologia da modernização, de uma forma ou de outra - seja com o desenvolvimentismo, seja com o neoliberalismo -, continua definindo em nossa sociedade o 'moderno' como a sociedade capitalista mais avançada, definição pautada na sociedade norte-americana e seu modo de vida. A enorme eficácia dessa ideologia se demonstra na sua capacidade de colocar o 'desenvolvimento' ou a 'modernização' como o nosso objetivo maior, que - apesar dos impasses e da comprovação empírica das colossais dívidas externas, resultados concretos das políticas desenvolvimentistas, e do fosso que só faz agravar-se entre os países como o nosso e o chamado Primeiro Mundo - se mantém na ideologia política e econômica como alcançável no futuro, sempre adiado.

Essa dominância da modernização não se exerceu unicamente como ideologia, no mundo social, no econômico e no político. Ela alcançou em cheio as ciências sociais e o mundo acadêmico, especialmente nas décadas de 1950 e 1960, oferecendo suporte ‘teórico’ para as políticas desenvolvimentistas. Tanto no plano das teorias quanto no das políticas, o desenvolvimento é sempre tratado em termos nacionais, referido em cada caso a um determinado Estadonação. O desenvolvimento é sempre desenvolvimento nacional. A teoria da modernização chega a prever a necessidade de uma ideologia para dar sustentação e legitimidade social à promoção acelerada da modernização ou desenvolvimento. Talcott Parsons, o maior expoente teórico da modernização, diz: “in 
this discussion, I have broadly located the center of developmental initiative in a bureaucratic political structure, and outlined an ideological setting within which development is likely to take place”. Afirma que há uma determinada direção desejada, "the impetus to economic development under non-Communist auspices", o que depende de agenciamento a ser conduzido na esfera política nacional local. Parsons define a ideologia que convém para dar sustentação a esse agenciamento: "the nationalistic-developmental complex of ideology" (Parsons, 1960:124, 125, 126). Não descreve um processo histórico real, propõe uma direção política a ser construída nas regiões que a política do capital pretende 'modernizar'.

Rapidamente a teoria da modernização tornou-se dominante nas ciências sociais na academia, ao mesmo tempo que o desenvolvimento se tornava ideologia dominante em países como o Brasil (Cardoso, 1972). É nesse contexto que Florestan Fernandes se afasta dessas duas influências e as submete à crítica que as supera teoricamente, produzindo assim um importante contraponto para alcançar a especificidade dos países que a teoria da modernização designava como 'tradicionais' e que a teoria do desenvolvimento passou a chamar de 'subdesenvolvidos'. Esse contraponto provinha de outra formação teórica e questionou a fundo aquelas 'teorias'. Refiro-me à produção do conceito e da teorização do capitalismo dependente por Florestan Fernandes.

Para pensar 'o Brasil' e explicá-lo, Florestan entende que é necessário alcançar as relações que o determinam estrutural e dinamicamente. Nessa busca, adota como critério metodológico que "o importante e decisivo não está no passado, remoto ou recente, mas nas forças em confronto histórico, em luta pelo controle do Estado e do alcance da mudança social" (Fernandes, 1974:209210). O passado colonial é importante, mas não é o passado que explica o presente; é preciso situar o objeto no conjunto das forças sociais em confronto na situação atual. Florestan logo compreende que apenas em parte essas forças sociais se encontram dentro dos limites do Estado-nação. Preocupa-o por que, com a Independência, não nos tornamos independentes de fato. A questão não se resolve no plano político-jurídico. A sociedade nacional não se constitui como uma totalidade autodefinível. É necessário colocá-la como parte que é do capitalismo em expansão, para alcançar a sua especificidade nos processos de acumulação do capital que caracterizam essa expansão num momento determinado.

$\mathrm{Na}$ formulação de Florestan Fernandes, a expansão do capitalismo monopolista cria capitalismo dependente. ${ }^{5} \mathrm{O}$ Brasil se inscreve nessa expansão 
da seguinte forma: o país é uma particularidade que pertence à generalidade capitalismo por meio da especificidade capitalismo dependente. Florestan descobre que a 'integração' de países do mesmo tipo que o Brasil à expansão capitalista é propriamente uma forma, particular e específica, que o desenvolvimento capitalista assume nas economias dependentes. Formula então o capitalismo dependente como conceito. Capitalismo dependente é uma forma que o desenvolvimento capitalista assume na sua fase monopolista. Numa das formulações mais abrangentes do conceito no plano econômico, Florestan o define como

uma economia de mercado capitalista constituída para operar, estrutural e dinamicamente: como uma entidade especializada, ao nível da integração do mercado capitalista mundial; como uma entidade subsidiária e dependente, ao nível das aplicações reprodutivas do excedente econômico das sociedades desenvolvidas; e como uma entidade tributária, ao nível do ciclo de apropriação capitalista internacional, no qual ela aparece como uma fonte de incrementação ou de multiplicação do excedente econômico das economias capitalistas hegemônicas. (Fernandes, 1968:36-37)

O conceito de capitalismo dependente inclui necessariamente as classes sociais. Segundo Florestan, a explicação sociológica do subdesenvolvimento deve

ser procurada no mesmo fator que explica, sociologicamente, o desenvolvimento econômico sob o regime de produção capitalista: como as classes se organizam e cooperam ou lutam entre si para preservar, fortalecer e aperfeiçoar, ou extinguir, aquele regime social de produção econômica. (Fernandes, 1968:27-28)

Portanto, o capitalismo dependente não é atribuído exclusivamente a uma dominação externa. As burguesias locais são parceiras das burguesias hegemônicas. Como parceiras menores e subordinadas, mas parceiras, as chamadas burguesias 'nacionais' desempenham papel decisivo na articulação do capitalismo dependente com os centros mais dinâmicos da expansão capitalista. Desse modo, com a participação das classes sociais na análise, o conceito de capitalismo dependente permite produzir o "desmascaramento simultâneo" da dominação imperialista e das burguesias "nacionais" (Fernandes, 1995:143). Tendo compreendido a articulação das burguesias locais com a burguesia internacional, consegue-se entender a exacerbação da exploração capitalista do trabalho no capitalismo dependente. Como frações burguesas dependentes, tendo em vista 
a necessidade de partilha entre as burguesias parceiras, as burguesias locais criam expropriação e exploração excedentes.

A importância de uma concepção como essa não se esgota enquanto análise, mas traz conseqüências políticas da mais alta relevância. Não se trata de relações 'entre nações' nem propriamente de relações entre burguesias hegemônicas e burguesias dependentes. Trata-se de relações de dominação que se conjugam: dominação externa $e$ dominação interna. A dominação externa é realizada por meio da dominação interna, e esta se exerce não sobre um setor ou uma fração da burguesia, mas sobre o trabalho e a massa da população. Há, portanto, um padrão de acumulação de capital que é típico da relação de parceria desigual das burguesias envolvidas, que Florestan designa como "sobreapropriação repartida do excedente econômico" (Fernandes, 1973:57).

Desenvolver-se de modo desigual é próprio do capitalismo. A expansão do capital se faz criando desigualdades. O capitalismo opera como um sistema que desenvolve e integra ou exclui de maneira desigual as economias mais dinâmicas e as economias capitalistas dependentes. $\mathrm{O}$ capitalismo dependente, portanto, é uma forma subordinada da expansão 'normal' do capitalismo monopolista, é "a forma periférica e dependente do capitalismo monopolista, o que associa inexorável e inextricavelmente as formas 'nacionais' e 'estrangeiras' do capital financeiro" (Fernandes, 1985:50). Para Florestan, “a dominação econômica, sociocultural e política inerente ao imperialismo torna-se uma dominação total, que opera a partir de dentro dos países neocoloniais e dependentes e, ao mesmo tempo, afeta em profundidade todos os aspectos de sua vida econômica, sociocultural e política" (Fernandes, 1995:139).

Florestan estabelece uma relação entre a forma do campo econômico e a do campo político no capitalismo dependente. À superexploração e à superexpropriação econômica corresponde uma drástica redução da democracia. Na sociedade ainda mais desigual do capitalismo dependente, a democracia se torna uma democracia restrita, apenas uma democracia de iguais. Desse modo, o capitalismo dependente é caracterizado como sobreexploração/ sobreexpropriação e como autocracia.

No capitalismo subordinado ou dependente, a desigualdade que é própria do desenvolvimento capitalista se torna extremada: uma minoria social dominante retém para si todos os privilégios como se fossem direitos e exclui de todos os direitos a grande maioria da sociedade, como se isso fosse natural. 
Florestan caracteriza a dominação da burguesia local no capitalismo dependente como tirânica. Esclarece que não se trata

apenas de defender a 'liberdade' e a 'democracia'. Porém, de pôr em evidência que a sociedade de classes engendrada pelo capitalismo na periferia é incompatível com a universalidade dos direitos humanos: ela desemboca em uma democracia restrita e em um Estado autocrático-burguês, pelos quais a transformação capitalista se completa apenas em benefício de uma reduzida minoria privilegiada e dos interesses estrangeiros com os quais ela se articula institucionalmente. (Fernandes, 1980:77)

No capitalismo dependente, a autocracia é uma característica permanente da forma de dominação que as burguesias dependentes adotam, não é uma exceção. Com a caracterização do político como autocracia, completa-se o que Florestan Fernandes compreende por capitalismo selvagem.

A análise da condição capitalista dependente do Brasil e da América Latina mostra as dificuldades que essa condição apresenta para a sua transformação:

Não cabe ao sociólogo negar alternativas à transformação das sociedades humanas. Elas existem, o difícil seria prognosticar qual delas poderá ocorrer. Na América Latina, ao que parece, as burguesias perderam a oportunidade histórica de se tornarem agentes da transformação concomitante das formas econômicas, sociais e políticas inerentes ao capitalismo. Por isso, o avanço nessa direção tende a fazer-se, ainda em nossos dias, como processo de modernização, sob o impacto da incorporação dos sistemas de produção e dos mercados latino-americanos às grandes organizações da economia mundial. As burguesias de hoje por vezes imitam os grandes proprietários rurais do século XIX. Apegam-se ao subterfúgio do desenvolvimentismo como aqueles apelaram para o liberalismo: para disfarçar uma posição heteronômica e secundária. $\mathrm{O}$ desenvolvimentismo encobre, assim, sua submissão a influências externas, que se supõem incontornáveis e imbatíveis. A mesma coisa acontece com o nacionalismo exacerbado. Quando ele reponta, no seio dessas burguesias, quase sempre oculta algo pior que o fracasso histórico e a frustração econômica: envolve uma busca de esteios para deter a torrente histórica e preservar o próprio capitalismo dependente, e segundo valores provincianos. (Fernandes, 1968:101)

A transformação é objetivamente possível, mas é travada, especialmente em termos ideológicos, pelos poderosos interesses do capitalismo dependente e do desenvolvimento capitalista dependente. 


\section{A Sociedade em que Vivemos sob o Capital MUNDIALIZADO}

\section{A CRISE}

Hobsbawm, para quem o século XX foi breve (de 1914 a 1991), afirma não haver dúvida de que dos últimos anos da década de 1980 aos primeiros da década de 1990 se define um período que marca o encerramento de uma era e o começo de uma nova era no capitalismo. O século XX se iniciou por uma 'era de catástrofe' (definida pelas duas grandes guerras mundiais), seguida por uma 'era de ouro' (compreendendo os 25 ou trinta anos de extraordinário crescimento econômico e transformação social), e desde os anos 1970 se instalou uma 'era de decomposição, incerteza e crise', que Hobsbawm designa como uma "melancolia fin-de-siècle" (Hobsbawm, 1997:15). A crise é econômica, política, social e moral (Hobsbawm, 1997:20), e o clima é de insegurança e de ressentimento (Hobsbawm, 1997:397-398).

Para Wallerstein, no entanto, o que se descobriu recentemente como 'globalização', que estaria mudando completamente o nosso mundo, "is nothing but the basic operating principle of the capitalist world-economy" (Wallerstein, 2001:viii). Com sua perspectiva do sistema-mundo, Wallerstein afirma que a cadeia transnacional de mercadorias é extensiva desde a própria constituição do capitalismo como sistema e se tornou global desde a segunda metade do século XIX. Entende que o sistema não sofreu transformações profundas ou estruturais ao longo do século XX:

To be sure, the improvement in technology has made it possible to transport more and different kinds of items across great distances, but I contend that there has not been any fundamental change in the twentieth century, and that none is likely to occur because of the so-called information revolution. (Wallerstein, 1999:59)

Assim, com a globalização ou com a revolução informacional, o capitalismo não acabou nem sofreu transformação fundamental na sua estrutura.

Contrariamente ao discurso ultraliberal - que apresenta a globalização como resultado 'inevitável' do jogo livre das leis do mercado, sob uma concorrência globalizada e liberada de todos os 'entraves' das regulamentações públicas, o que favoreceria afinal o 'consumidor', que agora teria acesso livre ao 
circuito também livre de mercadorias em âmbito mundial -, Chesnais (1995) observa que o conteúdo efetivo da globalização não se refere à mundialização das trocas, mas à mundialização das operações do capital, tanto na sua forma industrial quanto na sua forma financeira. Identifica no contexto macroeconômico mundial uma nova fase no processo de internacionalização, sob um novo regime mundial de acumulação. Estuda as "mudanças estruturais maiores da economia capitalista mundial das duas últimas décadas" e procura compreendê-las "com a ajuda da noção de regime de acumulação com dominância financeira" (Chesnais, 2003:45).

Arrighi, apoiado metodologicamente na perspectiva da 'longa duração' (Braudel), diferentemente de Hobsbawm fala do 'longo século XX', entendendo que a partir da década de 1970 tem início uma modificação fundamental do capitalismo, que é preciso analisar nos termos dos processos mundiais de acumulação de capital. Diz, porém, que essas transformações em curso apenas aparentemente são revolucionárias: nos anos 1970 e 1980 se verifica uma tendência predominante de acumulação de capital em escala mundial que é crescentemente financeira, mas "não parece ser uma tendência nada 'revolucionária” (Arrighi, 1996:309). Recorrendo a Braudel, entende que

o capital financeiro não é uma etapa especial do capitalismo mundial, muito menos seu estágio mais recente e avançado. Ao contrário, é um fenômeno recorrente (...). Ao longo de toda a era capitalista, as expansões financeiras assinalaram a transição de um regime de acumulação em escala mundial para outro. Elas são aspectos integrantes da destruição recorrente de 'antigos' regimes e da criação simultânea de 'novos'. (Arrighi, 1996:ix-x)

Sob essa perspectiva, Arrighi supõe que a atual expansão financeira corresponde ao momento conclusivo de um determinado estágio de desenvolvimento do sistema capitalista mundial.

Em análises realizadas em outro registro, Hardt e Negri sustentam que na segunda metade do século XX ocorreu uma profunda transformação pela qual se configura uma nova realidade. Falam da "globalização irresistível e irreversível de trocas econômicas e culturais" (Hardt \& Negri, 2005a:11). Dizem que,

juntamente com o mercado global e com circuitos globais de produção, surgiu uma ordem global, uma nova lógica e estrutura de comando - em resumo, uma nova forma de supremacia. O Império é a substância 
política que, de fato, regula essas permutas globais, o poder supremo que governa o mundo. (Hardt \& Negri, 2005a:11)

Para os dois autores, essa é uma realidade efetivamente nova, distinta do imperialismo.

A transição para o Império surge do crepúsculo da soberania moderna. Em contraste com o imperialismo, o Império não estabelece um centro territorial de poder, nem se baseia em fronteiras ou barreiras fixas. É um aparelho de descentralização e desterritorialização do geral que incorpora gradualmente o mundo inteiro dentro de suas fronteiras abertas e em expansão. O Império administra entidades híbridas, hierarquias flexíveis e permutas plurais por meio de estruturas de comando reguladoras. As distintas cores nacionais do mapa imperialista do mundo se uniram e mesclaram num arco-íris imperial global. (Hardt e Negri, 2005a:12-13)

Identificam nessa transformação "uma mudança no modo capitalista de produção” (Hardt \& Negri, 2005a:13). Numa reflexão sobre metodologia, propõem a necessidade de rever a Introducão de 1857, de Marx, para permitir sua aplicação "na transformação". Afirmam: "Hoje precisamos de uma nova Einleitung, porque a essência do capitalismo (sua maturidade e sua estabilização global) está radicalmente modificada" (Negri, 2003:241). Para Hardt e Negri, essa transformação caracteriza os estilos históricos da pós-modernidade.

\section{O ESTADO}

Os estudos sobre o desenvolvimento capitalista atual se detêm sobre a questão do Estado, acentuando suas novas funções ou o deslocamento da soberania. Segundo Wallerstein, hoje há sinais de crise no capitalismo no âmbito da soberania do Estado nacional. A peculiaridade a observar é que estados são soberanos dentro de um sistema interestatal. A soberania reclamada pelos estados desde o século XVI não diz respeito propriamente ao Estado como tal, mas ao sistema interestatal. É uma pretensão dupla, porque voltada para dentro e para fora do Estado. A soberania do Estado 'para dentro', no limite do seu território, autoriza esse Estado a definir e aplicar as políticas e as leis julgadas apropriadas ou necessárias, tendo garantido o direito de vê-las obedecidas por todos os que fazem parte desse Estado. A soberania do Estado 'para fora' garante a esse Estado a não-interferência de outro Estado dentro dos limites do Estado em questão. Neste sentido, a soberania envolve o reconhecimento mútuo dessas pretensões de cada Estado no sistema interestatal. “That is, sovereignty 
in the modern world is a reciprocal concept" (Wallerstein, 1999:60). A soberania dos Estados dentro do sistema interestatal "is a fundamental pillar of the capitalist world-economy. If it falls, or seriously declines, capitalism is untenable as a system" (Wallerstein, 1999:74). Daí por que o declínio que é possível observar hoje na soberania dos Estados pode ser tomado como um sinal importante da crise aguda por que passa atualmente o capitalismo como um sistema histórico.

Wallerstein argumenta, porém, que os capitalistas dependem da intervenção dos Estados de tantas maneiras que "any true weakening of state authority is disastrous" (Wallerstein, 1999:73). Daí por que

the essential dilemma of capitalists, singly and as a class, is whether to take full short-run advantage of the weakening of the states, or to try short-run repair to restore the legitimacy of the state structures, or to spend their energy trying to construct an alternative system. Behind the rhetoric, intelligent defenders of the status quo are aware of this critical situation. (Wallerstein, 1999:74)

Arrighi aponta uma fusão singular do Estado com o capital nessa fase. Cita Max Weber ao mostrar como o desenvolvimento do capitalismo moderno dependeu do Estado nacional, de tal modo que o capitalismo persistirá enquanto o Estado nacional não der lugar a um império mundial. ${ }^{6}$ Para Arrighi (1996:343), está havendo um "definhamento do moderno sistema de Estados territoriais como locus primário do poder mundial”, o que estaria levando a uma busca de formas interestatais de governo mundial.

Os Estados nacionais já não são mais soberanos, segundo Hardt e Negri. O Estado-nação perdeu algumas de suas prerrogativas fundamentais e vem redefinindo suas funções, concentradas sobretudo nas questões de segurança e de ordem pública interna (Negri, 2003:38). O comando efetivo já não se encontra mais no nível do Estado-nação. A hipótese básica é que "a soberania tomou nova forma, composta de uma série de organismos nacionais e supranacionais, unidos por uma lógica ou regra única" (Hardt \& Negri, 2005a:12). A soberania imperial não se localiza em nenhum Estado-nação. "Os Estados Unidos não são, e nenhum outro Estado-nação poderia ser, o centro de um novo projeto imperialista” (Hardt \& Negri, 2005a:13-14). Neste sentido, é contraproducente que a luta contra o Império tenha como alvo os EUA, sob a suposição de que o comando do Império estaria nas mãos do governo norteamericano. Nenhum país, nem os EUA nem qualquer outro, irá ocupar a posição de comando imperial de forma semelhante à que os Estados-nação 
então hegemônicos ocuparam no imperialismo. Para Hardt e Negri (2005a:14), "O imperialismo acabou". "A soberania imperial se encontra em um 'nãolugar"” (Negri, 2003:12).

As grandes corporações não operam mais como no imperialismo, elas "estruturam e articulam territórios e populações", criando uma nova geografia mundial, "uma nova estruturação biopolítica do mundo" (Hardt \& Negri, 2005a:50-51). Essa nova estruturação global, que constitui um mundo sulcado, cujas "estrias" se apresentam "cada vez mais móveis e dinâmicas" (Negri, 2003:13), requer uma regulamentação que substitua não apenas de fato, mas também de direito, a regulamentação estatal, que atualmente já está de várias maneiras subordinada a decisões, determinações e controles supranacionais. Hardt e Negri sustentam que não há globalização sem regulamentação e, com isso, se dedicam à análise jurídico-política que se aplique ao nível imperial, em substituição ao direito internacional.

Arrighi, no entanto, concentra a atenção em como a mundialização do capital reflete mudanças qualitativas nas relações de forças políticas entre o capital e o Estado e entre o capital e o trabalho. Especialmente sob o impacto das novas tecnologias aplicadas à produção industrial, o capital reorganiza seu processo de internacionalização e modifica suas relações com o trabalho, sobretudo no setor industrial, fazendo desregulamentar antigos 'direitos' trabalhistas e adotando crescentemente o que chama de 'flexibilização' dos contratos salariais, que estabelecem na verdade novas relações de precarização do emprego. Num quadro de desemprego estrutural, essa precarização enfraquece ainda mais o trabalho frente ao capital.

Chesnais avança a compreensão desse processo. Enfatiza a importância do Estado para o estabelecimento do novo regime mundial de acumulação, já que são os Estados que, se não formulam, implementam as políticas de liberalização, desregulamentação e privatização que esse regime de acumulação mundial requer. Esse regime se caracteriza pelo oligopólio mundial, fruto da progressão quantitativa e qualitativa dos movimentos conjugados de centralização e de concentração do capital industrial. Chesnais reconhece uma nova configuração das multinacionais, constituídas por grupos financeiros com dominância industrial (que já não são mais propriamente 'empresas' ou 'firmas'), com alto grau de financeirização e tendência para fortalecer o capital rentista. 


\section{A POLARIZAÇÃO}

Hobsbawm se detém no contraponto entre o que chama de "teologia" ultraliberal do livre-mercado e o desemprego estrutural, a agudização da pobreza e da miséria (com um aumento impressionante da desigualdade econômica e social e o reaparecimento de miseráveis sem-teto) e o crescimento vertiginoso da dívida, seguido da clara decisão por parte da economia mundial capitalista de "cancelar uma grande parte do Terceiro Mundo". O que o leva a concluir que "o principal efeito das Décadas de Crise foi assim ampliar o fosso entre países ricos e pobres” (Hobsbawm, 1997:413).

Arrighi identifica uma tendência recorrente nos processos de financeirização (por exemplo, na Espanha na primeira década de 1600, na Florença renascentista, nos Estados Unidos no final do século XX). Cada um desses processos tem acentuado de forma extrema o contraste entre ricos e pobres num mesmo país. Atualmente, esses efeitos polarizadores da financeirização alcançam escala mundial, acompanhando a reorganização da economia capitalista, que tenta recuperar-se das suas crises em bases sempre maiores, ampliando, portanto, sua esfera de ação em escala mundial, acentuando ainda mais a polarização também nesse nível.

Também Chesnais vincula a mundialização do capital à polarização da riqueza, primeiramente interna a cada país, em seguida internacional, cavando um fosso brutal entre "os países localizados no coração do oligopólio mundial e aqueles que ficam na periferia deste" (Chesnais, 1995:15), os quais passam a ser objetos de integração seletiva e, no caso de um grande número de países pobres, de desconexão (que os transforma em 'zonas de pobreza'), em função das escolhas para a localização dos investimentos globais. O regime de acumulação com dominância financeira “é uma 'produção' dos países capitalistas avançados, com os Estados Unidos e o Reino Unido à frente” (Chesnais, 2003:52). Para Chesnais,

este regime é indissociável das derrotas sofridas pela classe operária ocidental, bem como da restauração capitalista na ex-União Soviética e nas pretensas 'democracias populares'. Ele não é mundializado no sentido em que englobaria o conjunto da economia mundial numa totalidade sistêmica. Inversamente, ele é efetivamente mundializado no sentido em que seu funcionamento exige, a ponto de ser consubstancial à sua existência, um grau bastante elevado de liberalização e de desregulamenta- 
ção não apenas da finança, mas também do investimento externo direto

(...) e das trocas comerciais. (Chesnais, 2003:52)

Sob esse regime de acumulação, as medidas de liberalização e desregulamentação devem ser impostas em todos os lugares, mundo afora. A mundialização que resulta do regime de acumulação com dominância financeira "possui, de modo evidente, a função de garantir a apropriação, em condições tão regulares e seguras quanto possível, das rendas financeiras - juros e dividendos - numa escala mundial" (Chesnais, 2003:53).

II

Une critique (...) consiste à voir sur quels types d'évidences, de familiarités, de modes de pensée acquis et non réfléchis reposent les pratiques que l'on accepte. (...) La critique consiste à débusquer cette pensée et à essayer de la changer. (...) Dans ces conditions, la critique (et la critique radicale) est absolument indispensable pour toute transformation. Car une transformation qui resterait dans le même mode de pensée, une transformation qui ne serait qu'une certaine manière de mieux ajuster la même pensée à la réalité des choses ne serait qu'une transformation superficielle.

Michel Foucault, 1981 (in Foucault, 1994, t.4:180-181)

Les dominés (...) ne peuvent se constituer en groupe séparé, se mobiliser et mobiliser la force qu'ils détiennent à l'état potentiel qu'à condition de mettre en question les catégories de perception de l'ordre social qui, étant le produit de cet ordre, leur imposent la reconnaissance de cet ordre, donc la soumission.

Pierre Bourdieu, 1982 (in Bourdieu, 1982:151)

Ce n'est pas la simple présence du vrai qui le fait connaître comme vrai.

Louis Althusser, 1984-1987 (in Althusser, 1994a, I:69)

As relações sociais construídas pelo capital se estabelecem, se mantêm e se reforçam por meio de múltiplos mecanismos de dominação, administrados por diferentes tecnologias de poder e inculcados nos diversos aparelhos ideológicos do Estado, ou impostos repressivamente. Entre os autores decisivos para o entendimento dessas construções sociais históricas se destacam Marx, Althusser e Foucault. 


\section{A Subsunção do Trabalho sob o Capital}

Com a distinção entre a subsunção formal e a subsunção real do trabalho sob o capital, no esboço para o capítulo VI (chamado capítulo inédito) de $O$ Capital (Marx, 1968), Marx retoma sob esses conceitos a distinção entre a chamada acumulação primitiva e a acumulação capitalista. Encaminha assim a resolução do paradoxo que havia colocado no início do capítulo sobre a acumulação primitiva no Capital.

Hemos visto cómo se convierte el dinero en capital, cómo sale de éste la plusvalía y cómo la plusvalía engendra nuevo capital. Sin embargo, la acumulación de capital presupone la plusvalía, la plusvalía la producción capitalista y ésta la existencia en manos de los productores de mercancías de grandes masas de capital y fuerza de trabajo. Todo este proceso parece moverse dentro de un círculo vicioso, del que sólo podemos salir dando por supuesta una acumulación 'originaria' anterior a la acumulación capitalista ("previous accumulation", la denomina Adam Smith); una acumulación que no es resultado, sino punto de partida del régimen capitalista de producción. (Marx, 2000:607)

A implantação do capitalismo depende de que haja acumulação capitalista, que por sua vez depende da existência de capital, portanto acumulado previamente ao estabelecimento do capitalismo como tal. De acordo com Marx, essa acumulação se chama primitiva, ou originária, porque pertence à "préhistória do capital e do regime capitalista de produção" (Marx, 2000:608).

Os conteúdos históricos da subsunção formal e real do trabalho sob o capital já aparecem no capítulo da acumulação primitiva, embora aí se achem apenas indicados. Marx diz, por exemplo, que, quando na acumulação primitiva o capital converte diretamente o escravo e o servo da gleba em operário assalariado, determina uma simples "mudança de forma" (Marx, 2000:647). Desde então, vincula a acumulação do capital à expropriação dos meios de trabalho. Afirma que a acumulação primitiva "significa pura y exclusivamente la expropiación del productor directo” (Marx, 2000:647).

La propiedad privada fruto del propio trabajo y basada, por así decirlo, en la compenetración del obrero individual e independiente con sus condiciones de trabajo, es devorada por la propiedad privada capitalista, basada en la explotación del trabajo ajeno, aunque formalmente libre. (Marx, 2000:648) 
O regime do capital pressupõe a separação entre o operário e a propriedade dos meios de realização do seu trabalho. Diz Marx:

Cuando ya se mueve por sus propios pies, la producción capitalista no sólo mantiene este divorcio, sino que lo reproduce y acentúa en una escala cada vez. mayor. Por tanto, el proceso que engendra el capitalismo sólo puede ser uno: el proceso de disociación entre el obrero y la propiedad sobre las condiciones de su trabajo, proceso que de una parte convierte en capital los medios sociales de vida y de producción, mientras de otra parte convierte a los productores directos en obreros asalariados. (Marx, 2000:608)

O advento do capitalismo, que cria o assalariado e o capitalista, muda a forma de sujeição a que o trabalho é submetido, a exploração feudal se transforma em exploração capitalista (Marx, 2000). A expropriação que é antecedente necessário para o estabelecimento do capitalismo se faz com grande violência. Na realidade, diz Marx, os métodos da acumulação primitiva foram tudo, menos idílicos. "La expropiación del productor directo se lleva a cabo con el más despiadado vandalismo y bajo el acicate de las pasiones más infames, más sucias, más mezquinas y más odiosas” (Marx, 2000:648).

Antes de se estabelecer a subsunção real, o capitalista supervisiona um processo de trabalho já dado previamente, e o trabalho é subsumido apenas formalmente sob o capital. Até então, não há mudança essencial na forma real em que o trabalho é realizado. A jornada mais extensa e o trabalho mais intenso, mais contínuo e mais sistemático não mudam o caráter do modo real de trabalho. O que o capitalista persegue aí é a produção de mais-valia absoluta, procurando maximizar o produto e minimizar os custos da produção, especialmente o custo da utilização do trabalho.

Na subsunção formal do trabalho sob o capital, o processo de trabalho é para o capitalista processo de exploração de trabalho alheio. Depende de que o produtor direto tenha sido expropriado dos meios de produção, agora propriedade do capital. Já não tendo como garantir a própria subsistência, se vê assim compelido a vender não o seu trabalho, mas a sua força de trabalho em troca de um salário e, como assalariado, passa a trabalhar sob o comando, a supervisão e a direção do capital.

A relação-de-capital é uma relação de compulsão. Com a subsunção formal do trabalho sob o capital, essa compulsão não se baseia em nenhuma relação pessoal de dominação e dependência. Ela se instala basicamente em decorrência da diferença de funções econômicas. No modo de produção capita- 
lista, a subordinação que se estabelece entre vendedor e comprador da mercadoria força de trabalho não decorre de nenhuma subordinação de caráter político ou social que seja anterior à relação de compra-e-venda: “Ce n'est qu'en tant que propriétaire des conditions de travail que l'acheteur place le vendeur sous sa dépendance économique; il n'y a pas de rapport, politiquement et socialement fixé, de suprématie et de subordination" (Marx, 1968:370). A comparação feita aqui se dirige claramente às formas anteriores de organização da produção, em que o produtor direto não era formalmente livre para oferecer a sua força de trabalho a um comprador qualquer, pelos vínculos de subordinação que o prendiam à terra, ao senhor, à guilda etc., sob relações fixadas política e socialmente.

Enquanto prevalece uma subsunção formal do trabalho ao capital, instala-se, pois, uma relação econômica de dominação e subordinação entre trabalho e capital. Diz Marx:

Lorsque les rapports de domination et de subordination se substituent à l'esclavage, au servage, au vassalage, au patriarcat, etc., ils ne subissent qu'un changement de forme. Libres formellement, ils n'ont désormais qu'un caractère objectif, volontaire, purement économique. (Marx, 1968:372)

Há uma mudança na forma da relação de dominação e subordinação. Essa relação se torna mais livre. Como o trabalhador é formalmente livre, sua subordinação ao capital é formalmente voluntária. Neste sentido, é 'puramente econômica'. Marx indica, porém: 'Bien sûr, ce mode de production crée à son tour un nouveau rapport hiérarchique de domination et de subordination (lequel, de son côté, produit ses propres expressions politiques, etc.)" (Marx, 1968:371). O estabelecimento do modo de produção especificamente capitalista produz uma nova e efetiva relação de dominação e subordinação a partir do próprio processo produtivo, processo que antes se caracterizava por independência. $\mathrm{Na}$ organização social e do trabalho que prevalecia anteriormente, o produtor direto era subordinado a um senhor, à terra ou a um grêmio, mas na realização do seu trabalho dispunha de independência e de controle sobre o processo de trabalho. Com o capitalismo, ele perde essa independência.

Em seguida à expropriação do produtor direto ocorre a centralização dos capitais, que é inerente à produção capitalista. Esta centralização consiste na "expropriação de muitos capitalistas por uns poucos" e acarreta, como conseqüência, as mudanças profundas na própria maneira de produzir que caracterizam o capitalismo: 
...se desarrolla en una escala cada vez mayor la forma cooperativa del proceso de trabajo, la aplicación técnica consciente de la ciencia, la explotación sistemática y organizada de la tierra, la transformación de los medios de trabajo en medios de trabajo utilizables sólo colectivamente, la economía de todos los medios de producción al ser empleados como medios de producción de un trabajo combinado, social, la absorción de todos los países por la red del mercado mundial y, como consecuencia de esto, el carácter internacional del régimen capitalista. (Marx, 2000:648)

Assim se define a especificidade do modo capitalista de produzir.

Sendo capitalista a forma de produção, o processo de trabalho está sempre diretamente subordinado ao capital. Mas com o modo especificamente capitalista de produção, específico tecnologicamente e também sob outros aspectos, transforma-se a natureza real do processo de trabalho e suas condições reais. Diz Marx:

Avec elle [la subordination réelle du travail au capital], une révolution totale (et sans cesse renouvelée) s'accomplit dans le mode de production lui-même, dans la productivité du travail et dans les rapports entre le capitaliste et le travailleur. (Marx, 1968:379)

O modo de produção capitalista, segundo Marx um modo de produção sui generis, muda a configuração da produção material, sobre a qual se baseia a relação-de-capital.

Com a distinção entre subsunção formal e subsunção real do trabalho sob o capital, Marx procura marcar o 'grande contraste' entre o modo especificamente capitalista de produção e as formas anteriores, mesmo a forma imediatamente anterior, já sob o comando do capital. Somente com a subsunção real do trabalho sob o capital surge o modo de produção específico ao capitalismo, que não revoluciona apenas o tipo de trabalho e o modo real de todo o processo de trabalho, mas revoluciona também, ao mesmo tempo, as relações entre os diferentes agentes da produção. Com a implantação desse modo específico começam a se formar as relações de produção específicas dele; o capital estabelece relações de produção novas. É no interior do processo de trabalho que aqueles que antes apareciam apenas como comprador e vendedor da mercadoria força de trabalho se tornam agentes personificados dos fatores de produção: o capitalista funciona como 'capital' e o produtor direto como 'trabalho'. A relação que se forma entre trabalho e capital é determinada pelo trabalho. ${ }^{8}$ Aparece no início como meramente monetária, como relação entre um vendedor e um 
comprador - da nova mercadoria assim constituída, a força de trabalho. O processo de compra-e-venda dessa mercadoria, que aparece como uma relação entre possuidores de mercadorias dotados de direitos iguais, Marx diz que é apenas uma mediação - que é inerente ao modo de produção capitalista - que mascara como relação meramente monetária a relação propriamente capitalista subjacente, em que o trabalhador assalariado deve constantemente comprar de volta uma parte do seu próprio produto vendendo seu trabalho vivo. A renovação permanente da relação de compra-e-venda da força de trabalho mediatiza a continuidade da relação de dependência do trabalho ao capital que é específica do processo de produção capitalista.

No capítulo inédito, Marx conceitua os dois momentos da constituição do capitalismo como modo de produção particular e específico. A partir do processo de trabalho propriamente capitalista, o novo modo de produção constitui e coloca em confronto, de um lado, o trabalho, e de outro, o capital. No entanto, apesar desse confronto direto e diuturno na própria execução do trabalho, o processo produtivo capitalista mascara e mistifica as relações capitalistas que o engendram, de tal maneira que o que é produto do trabalho aparece ao trabalhador como se fosse produto do capital.

Marx identifica o processo de trabalho com o processo de valorização, porque supõe que é o trabalho despendido no processo produtivo que cria valor e sobre-valor (mais-valia). Assim, esse processo equivale ao processo do próprio capital. Mas o que é criação do trabalho aparece como se fosse criação do capital. De acordo com Marx, há uma mistificação que é inerente ao capitalismo:

la force de travail, conservatrice de la valeur, apparait comme la force du capital qui se conserve elle-même, la force de travail, créatice de la valeur, apparaît comme la force du capital qui se valorise elle-même. Dans l'ensemble, et par définition, le travail matérialisé apparaît comme l'employeur du travail vivant. (Marx, 1968:366)

Essa mistificação aumenta com a subsunção real do trabalho sob o capital, com o desenvolvimento da capacidade produtiva social ou socializada do trabalho, quando o caráter social do trabalho se confronta com o trabalhador como estranho a ele, hostil, antagônico, como capital personificado e objetivado.

A expansão do capital, produtora de muita riqueza, faz aumentar a miséria e a opressão de uma classe trabalhadora que o próprio mecanismo do processo de produção une, organiza e disciplina (Marx, 2000:648). 
Quando Marx formula e distingue a subsunção formal e a subsunção real do trabalho sob o capital, focaliza pontos essenciais para o entendimento do modo de produção capitalista: 1) que as relações de produção capitalistas se constroem com e no próprio processo produtivo capitalista, junto com a realização do trabalho na fábrica; 2) que os mecanismos de exploração e de dominação (submissão, subjugação) operam juntos, ditados pelo processo de trabalho e necessários a ele; 3) que todo esse processo constitui e contrapõe as duas classes fundamentais desse modo de produção: o trabalho e o capital; 4) que é inerente ao modo de produção capitalista a mistificação por meio da qual o que é produção do trabalho apareça como sendo produção do capital.

\section{Aparelhos Ideológicos de Estado}

Althusser tomou como objeto privilegiado da sua investigação as relações de dominação e subordinação engendradas pelas relações de produção capitalistas, especialmente por meio da ideologia, que supunha mistificadora. São conhecidos os seus primeiros grandes textos sobre a reprodução das relações sociais. Mas vários especialistas consideram que, especialmente entre 1976 e 1978, Althusser desconstrói (Sintomer, 'Présentation a Althusser', Althusser, 1998) ou mesmo destrói (Balibar, 1991) sua produção anterior. ${ }^{9}$ Em texto de 1993, Negri aponta a existência de uma 'Kehre' no pensamento de Althusser. ${ }^{10}$ Recorre aos Arquivos do Imec (Institut Mémoire de l'Édition Contemporaine) e se detém especialmente em textos inéditos ou em partes inéditas de textos já publicados. Aqui me interessa sobretudo a questão da 'sociedade capitalista da subsunção real', que Negri apreende no fundo da suposta 'Kehre' althusseriana. Segundo Negri, a transformação conceitual que ocorre nessa grande 'virada' do pensamento de Althusser consiste no aprofundamento contínuo da temática dos Aparelhos Ideológicos de Estado(AIE).

Sabemos que, inicialmente, Althusser considerava os AIE como os lugares da reprodução social, lugares de produção/reprodução da ideologia, cuja existência social e material se constituía nesses aparelhos e por meio deles. Adotava então a perspectiva da reprodução das relações sociais. Segundo Negri, a nova concepção althusseriana corresponde a uma nova realidade social engendrada pelo próprio desenvolvimento capitalista. Nessa nova realidade capitalista, a ideologia estende sua dominação massivamente sobre todo o real, configu- 
rando uma situação de dominação social totalitária da ideologia (Negri, 1993). Negri diz que Althusser define 'pós-moderno' "comme de l'expansion continu et de la contigüité totalitaire toujours plus intense du fonctionnement des AIE" (Negri, 1993:85). Entende que sobre essa continuidade e sobre essa contigüidade se efetua um salto qualitativo. Tal unificação dos AIE provoca uma "sobredeterminação da dominação", e essa ampliação "pós-moderna" do poder dos AIE unificados configura a "sociedade capitalista da subsunção real", em que a realidade social se confunde com a ideologia e o poder capitalista se reafirma como controle ideológico total.

Sobre o pensamento de Althusser a respeito da sociedade capitalista pósmoderna, Negri diz: “désormais l'exploitation plus qu'elle ne traverse les lignes de division entre les classes, s'insinue davantage dans les consciences et les dimensions subjectives de tous les acteurs sociaux" (Negri, 1993:86). Nesta sociedade em que o poder se funda no conjunto do processo social, o mundo é subsumido sob o capital. Pode-se presumir que esse poder é poder do capital, a dominação ideológica total é dominação do capital. Mas essa exploração que atravessa as linhas de divisão entre as classes e alcança todos não é, portanto, propriamente uma exploração de classe no sentido estrito. Negri, remetendo a Althusser, se refere a uma exploração que se insinua, para além das classes, sobre as consciências e a subjetividade de 'todos' os 'atores sociais'. A sociedade da dominação ideológica total é uma sociedade em que a exploração também é generalizada.

Estudando diretamente os textos de Althusser, pode-se verificar que a partir de 1976 ele revê e mesmo desconstrói muito da sua teorização anterior. Retifica alguns conceitos: fala em conjuntos contraditórios das ideologias, na existência tendencial de uma ideologia dominante, no papel importante da ideologia não apenas na reprodução, mas também na transformação das relações sociais (esp. Althusser, 1976, in Althusser, 1995b; Althusser, 1976, in Althuser, 1994a; e Althusser, 1972-1986, in Althusser, 1995a). Reforça outros conceitos, como o da materialidade da ideologia e da importância dos AIE (esp. Althusser, 1998, cap.13, e 1994a, II).

Nesse período, Althusser toma como objeto a crise do marxismo e entende que é preciso indagar à teoria marxista qual é sua parcela de responsabilidade nos horrores cometidos em nome do marxismo. Surge assim a necessidade de repensar Marx e o marxismo: 
Nous ne pouvons pas nous contenter de revenir en arrière, vers des positions qui auraient été seulement travesties ou trahies. La crise que nous vivons porte en elle des exigences nouvelles: elle nous oblige à changer quelque chose dans notre rapport au marxisme, et, par voie de conséquence, au marxisme même. (Althusser, 1998:273-274)

Althusser critica novamente o humanismo, critica a dialética, critica toda teleologia. E se volta para uma tradição materialista que reconhece desde Demócrito a Marx e Heidegger, em torno de categorias como vazio, limite, margens, ausência de centro, liberdade (Althusser, 1994a, I e 1994b, III). No entanto, há algo que nos primeiros grandes escritos $(1955-1967)^{11}$ fica praticamente fora da análise - embora permaneça como princípio assumido como tal - mas que nos últimos textos se torna parte integrante e com grande importância analítica: a questão das classes e da luta de classes. Por exemplo, falando da filosofia, afirma:

La tâche qui lui est assignée et déleguée par la lutte de classe en général, et plus directement par la lutte de classe idéologique, est celle de contribuer à l'unification des idéologies en idéologie dominante, et de garantir cette idéologie dominante comme Verité. (Althusser, 1994a, III:168)

O último Althusser recupera na análise da ideologia a perspectiva da transformação e entende a ideologia como parte da luta ideológica, componente específico da luta de classes.

Quanto à reprodução social, sua ênfase é na ideologia. Na entrevista a Fernanda Navarro, a propósito de uma questão sobre 'sujeito ideológico', Althusser diz:

C'est un fait que la reproduction sociale ne se réalise pas exclusivement à partir de la reproduction du travail, mais qu'elle suppose l'intervention fondamentale de l'idéologique. (...) Et bien que le moyen matériel pour reproduire la force de travail soit le salaire, celui-ci - comme nous le savons - ne suffit pas. Dès l'école, le travailleur a été 'formé' pour accomplir certaines normes sociales qui régulent des conduites: ponctualité, efficience, obéissance, responsabilité, amour familial et reconnaissance de toute forme d'autorité. Cette formation suppose l'assujetissement à l'idéologie dominante. (Althusser, 1994a, I:72-73)

No artigo de 1970 sobre os AIE (Althusser, 1995b:269-314), duas formulações são de grande interesse para a questão da subsunção real. Althusser diz que a reprodução das relações de produção é realizada pela materialidade 
do processo de produção e do processo de circulação através dos mecanismos desses processos e também pelo exercício do poder de Estado nos Aparelhos (os repressivos e os ideológicos) de Estado. Afirma ainda que, a não ser na ideologia dominante, não existe divisão técnica do trabalho, ou seja, toda divisão ou organização do trabalho constitui a forma e a máscara de uma divisão ou organização social (de classe) do trabalho. Reconhece, portanto, com toda a clareza, que a reprodução das relações sociais se faz primeiramente na 'materialidade do processo de produção', na qual a divisão e a organização técnicas do trabalho são a forma e a máscara de uma divisão e de uma organização sociais do trabalho. Reconhece ainda que essa divisão e essa organização sociais do trabalho são divisão e organização de classe. Desde os anos de crise, sempre que se refere à dimensão social, Althusser a entende em termos de classe, reservando o papel principal para as relações entre as classes como relações de exploração/dominação e de luta. É nesses termos que pensa a subordinação como parte da reprodução das relações sociais, preocupando-se permanentemente com a dimensão ideológica que a propicia.

Quando Negri fala do "totalitarismo da subsunção capitalista do social”, não parece estar expressando propriamente Althusser. Não encontro em Althusser referência ao conceito de subsunção da sociedade sob o capital. Minha hipótese de leitura é que se trata de uma interpretação feita por Negri sobre textos de Althusser que, no entanto, são formulados em outro registro conceitual. Uma leitura atenta revela que Negri explicita que a formulação da subsunção do mundo ao capital é sua, a partir do que lê em Althusser. Depois de dar conta dos novos estudos de Althusser sobre Maquiavel e sobre Spinoza, pergunta como fica, então, para Althusser, a relação entre a singularidade do trabalho vivo e a dominação abstrata do capital e do Estado, relação descrita por Marx e retomada por Althusser em Lire Le Capital (Althusser et al., 1965) e nos AIE. Negri (1993:82) diz que "ce rapport, considéré à d'autres moments dans son interaction, ne peut plus aujourd'hui être tenu pour tel”. Cita Althusser: "Maintenant les choses ont bien changé". E retoma a questão:

Que s'est-il passé vraiment? Il s'est passé que l'idéologie a massivement étendu sa domination sur tout le réel. Le réel se confond en grande partie avec l'idéologie. Si les AIE engendraient le pouvoir en le singularisant mécaniquement à travers diverses institutions, aujourd'hui ce pouvoir se fond dans l'ensemble du processus social. Le monde, dirions nous, a été subsumé sous le capital. (Negri, 1993:82, itálicos meus) 
$\mathrm{Na}$ verdade, a indicação parece clara de que quem fala de 'subsunção' não apenas especificamente do trabalho, mas 'do mundo' ou 'da sociedade' sob o capital, é Negri, interpretando Althusser quando este se refere à extensão massiva da ideologia sobre o conjunto do processo social. No entanto, como se trata de reflexões a partir de textos ainda inéditos, cabe manter a dúvida sobre se o próprio Althusser teria trabalhado nesses textos a "passagem à subsunção real da sociedade ao capital como totalidade do controle ideológico". É possível. Althusser assumiu idéias, conceitos e teses tão distintas das que havia adotado anteriormente que bem pode ter mudado quanto à questão da subsunção real.

\section{TeCnologias do Poder}

O que interessa sobretudo a Foucault é saber como funcionam as malhas do poder: "quelle est la localisation de chacun dans le filet du pouvoir, comment il l'exerce à nouveau, comment il le conserve, comment il le repércute" (Foucault, 1994:201). Trabalha com uma concepção de poder como tecnologia. Procura desembaraçar-se da concepção jurídica segundo a qual o poder é concebido a partir da regra, da lei, da proibição. Foucault quer discernir o funcionamento real do poder e não a sua representação. ${ }^{12}$ Entende que não há propriamente um poder, mas vários poderes, identificados com as formas de dominação e de sujeição que funcionam localmente (na oficina, no Exército etc.). Essas formas são heterogêneas e cada qual tem seu modo próprio de funcionamento, seus procedimentos e suas técnicas. A partir da existência inicial dessas pequenas regiões de poder se formam, pouco a pouco, os grandes aparelhos do Estado.

Foucault vincula o privilegiamento do poder como fato jurídico ao pensamento burguês e pretende seguir outro caminho para entender o poder. Quer alcançá-lo não na sua forma de Estado, pelo aparato político-jurídico do Estado, mas no seu funcionamento efetivo, que ele chama real, junto a cada um, a cada grupo, a cada classe. Pretende realçar as relações de dominação na sua multiplicidade, nas suas diferenças, na sua especificidade, na sua reversibilidade, para "essayer de repérer les differentes techniques de contrainte que (le pouvoir) met en œuvre" (Foucault, 1997:239). Busca, então, identificar táticas locais de dominação, instrumentos técnicos que asseguram as relações de dominação.

A sociedade é entendida por Foucault como um arquipélago de diferentes poderes, que não são simplesmente conseqüência de um poder central que 
seria primordial. Segundo ele, Marx mostra "comment, à partir de l'existence initiale et primitive de ces petites régions de pouvoir - comme la propriété, l'esclavage, l'atelier et aussi l'armée -, a pu se former, petit à petit, des grands appareils d'État" (Foucault, 1994:187). De acordo com Foucault, esses poderes locais não visam primeiramente proibir: eles têm como função essencial e permanente produzir uma eficiência, uma atitude.

Para Foucault, é preciso acompanhar a história dos saberes técnicos e tecnológicos no século XVIII. O que muitas vezes se considera como o progresso das Luzes, a luta do conhecimento contra a ignorância, da razão contra as quimeras, surge então como algo muito diferente: "un immense et multiple combat (...) des savoirs les uns contre les autres, par leurs détenteurs ennemis les uns des autres, et par leurs effets de pouvoir intrinsèques" (Foucault, 1997:159). A história desses saberes revela que eles são saberes múltiplos, independentes, heterogêneos e secretos e que o Estado intervém nas suas lutas, produzindo: 1) a eliminação e a desqualificação dos pequenos saberes inúteis e irredutíveis, economicamente onerosos; 2) a normalização dos saberes entre si, para tornar intercambiáveis os saberes e também aqueles que os detêm; 3) a hierarquização desses saberes; 4) uma centralização piramidal que permita controlar esses saberes, transmitir de baixo para cima os seus conteúdos e de cima para baixo a direção do conjunto e a organização geral que se quer fazer prevalecer (Foucault, 1997:161).

No entender de Foucault, o século XVIII foi o século da disciplinarização dos saberes a partir da 'ciência', que atuou como 'polícia disciplinar' dos saberes. O poder disciplinar se exerceu através da seleção, da normalização, da hierarquização e da centralização dos saberes. Foucault conclui que "sous ce qu'on a appelé le progrès de la raison, ce qui se passait c'était la mise en discipline de savoirs polymorphes et hétérogènes" (Foucault, 1997:162).

Foucault associa a invenção de novas tecnologias do poder ao desenvolvimento do capitalismo. Diz que é costume considerar como invenção decisiva nesse processo a máquina a vapor, mas encontra outras invenções tecnológicas às quais atribui importância igual ou mesmo maior do que aquela. Menciona tecnologias industriais e tecnologias políticas e entre estas destaca a disciplina e o controle. Encontra desde o fim do século XVII e durante o século XVIII o aparecimento de técnicas de poder essencialmente centradas no corpo individual. 
C'étaient toutes ces procedures par lesquelles on assurait la distribution spatiale des corps individuels (leur séparation, leur alignement, leur mise en série et en surveillance) et l'organisation, autour de ces corps individuels, de tout un champ de visibilité. C'étaient aussi ces techniques par lesquelles on prenait en charge ces corps, on essayait de majorer leur force utile par l'exercice, le dressage, etc. C'étaient également des techniques de rationalisation et d'économie stricte d'un pouvoir qui devait s'exercer, de la manière la moins coûteuse possible, par tout un système de surveillance, de hiérarchies, d'inspections, d'écritures, de rapports: toute cette technologie qu'on peut appeler technologie disciplinaire du travail. (Foucault, 1997:215)

A tecnologia disciplinar se centra no corpo individual - a vigiar, a vestir, a usar, a punir. A invenção da disciplina é assim uma forma de poder:

Comment surveiller quelqu'un, comment contrôler sa conduite, son comportement, ses aptitudes, comment intensifier sa performance, multiplier ses capacités, comment le mettre à la place où il sera plus utile: voilà ce qu'est, à mon sens, la discipline. (Foucault, 1994:191)

Na segunda metade do século XVIII, Foucault localiza a formação de uma outra tecnologia do poder, que não é disciplinar, mas não exclui a disciplina, a modifica, se implanta de algum modo nela e se estabelece graças a ela. Essa nova tecnologia se aplica à vida dos homens. Para Foucault, o controle é "l'autre grand noyau technologique autour duquel les procédés politiques de l'Occident se sont transformés. On a inventé à ce moment-là ce que j’appelerai, par opposition à l'anatomo-politique (...), la bio-politique” (Foucault, 1994:193). Isso ocorre quando

le pouvoir doit s'exercer sur les individus en tant qu'ils constituent une espèce d'entité biologique qui doit être prise en considération, si nous voulons précisément utiliser cette population comme machine pour produire, pour produire des richesses, des biens, produire d'autres individus. (Foucault, 1994:193)

De acordo com Foucault, estas são mudanças dos procedimentos políticos que acompanham a constituição do poder capitalista. Ambas são tecnologias do poder, cuja invenção "fait partie de ce développement dans la mesure où, d'un côté, c'est le développement du capitalisme qui a rendu nécessaire cette mutation technologique, mais cette mutation a rendu possible le développement du capitalisme" (Foucault, 1994:200). 
"Uma biopolítica da espécie humana", é como Foucault chama essa tecnologia que se dirige à multiplicidade dos homens enquanto "une masse globale, affectée de processus d'ensemble qui sont propres à la vie" (Foucault, 1997:216). Inclui um conjunto de processos, tais como

des processus de natalité, de mortalité, de longevité qui, justement dans la seconde moitié du XVIII ${ }^{e}$ siècle, en liaison avec tout un tas de problèmes économiques et politiques (...), ont constitué (...) les premiers objets de savoir et les premières cibles de contrôle de cette biopolitique. C'est à ce moment-là, en tout cas, que l'on met en œuvre la mesure statistique de ces phénomènes avec les premières démographies. (Foucault, 1997:216)

Em Foucault, a biopolítica - que se aplica, no limite, ao homem como espécie - é uma forma de "estatização do biológico" (Foucault, 1997:213).

A biopolítica lida com 'incapacidades biológicas diversas', tornadas objeto de saber, de cuidado e de políticas específicas por parte do poder. Foucault chama a atenção para o vínculo entre essa tecnologia de poder e o custo econômico das 'incapacidades biológicas diversas' a que se aplica. Destaca a importância das endemias enquanto "facteurs permanentes (...) de soustractions de forces, diminution du temps de travail, baisse d'énergies, coûts économiques, tant à cause du manque à produire que des soins qu'elles peuvent coûter. Bref, la maladie comme probème de population" (Foucault, 1997:217).

Assim, a instauração da biopolítica como tecnologia de poder trata de fenômenos que dão lugar a uma medicina que assume como função principal a higiene pública, através de organismos de coordenação dos cuidados médicos, de centralização da informação, de normalização do saber, e que se liga a todo um conjunto de procedimentos de medicalização da população (Foucault, 1997:217). Enquanto tecnologia de poder, a biopolítica já atuava por meio das instituições de assistência (muito mais antigas e em geral prestando uma assistência ao mesmo tempo massiva e lacunar), mas passa a atuar principalmente por meio de "mécanismes plus subtils, plus rationnels, d'assurance, d'épargne individuelle et collectif, de sécurité, etc." (Foucault, 1997:218).

Essa nova tecnologia de poder faz aparecer um elemento novo, não mais apenas o indivíduo como corpo, nem a sociedade como supostamente 'corpo' social, mas um novo corpo, "corps multiple, corps à nombre de têtes": é a noção de 'população', a população como problema ao mesmo tempo científico e político. Foucault ressalta a natureza dos fenômenos que desse modo 
são levados em consideração: são fenômenos coletivos, que só se tornam pertinentes como fenômenos de massa. Nas suas próprias palavras: "Ce sont des phénomènes qui sont aléatoires et imprevisibles si on les prend donc en euxmêmes, individuellement, mais qui présentent, au niveau collectif, des constantes qu'il est facile, en tout cas possible, d'établir" (Foucault, 1997:219). São fenômenos de série, que devem ser considerados num tempo mais ou menos longo, no curso de uma certa duração. Esse tipo de fenômeno é 'aleatório e imprevisível' quando considerado apenas na sua ocorrência singular, individual. Quando colocado como parte de um conjunto de fenômenos igualmente singulares, compreendidos numa duração mais ou menos longa, é possível estabelecer uma série do mesmo tipo, o que permite então tratá-los como generalidade e, nesse nível, alcançar suas determinações. A partir daí, torna-se possível fazer previsões e estimativas estatísticas. $\mathrm{O}$ objetivo não é intervir sobre um determinado fenômeno em particular, considerado em tal ou qual indivíduo singular. O que se pretende essencialmente é "intervenir au niveau de ce que sont les déterminations de ces phenomènes généraux, de ces phenomènes dans ce qu'ils ont de global" (Foucault, 1997:219). São, por exemplo, intervenções no sentido de baixar a morbidade, prolongar a vida, estimular a natalidade etc. Ou seja, essa tecnologia de poder tem a ver com a vida de uma população de seres vivos.

Com a biopolítica no sentido foucaultiano, visa-se estabelecer mecanismos reguladores numa determinada população considerada no seu conjunto, mecanismos que sejam capazes de manter um certo estado de equilíbrio quanto às variáveis pertinentes, "bref, d'installer des mécanismes de sécurité autour de cet aléatoire qui est inhérent à une population d'êtres vivants, d'optimaliser, si vous voulez, un état de vie" (Foucault, 1997:219). Tomar como objeto de regularização a vida, "os processos biológicos do homem-espécie" (Foucault, 1997:220). O poder que se investe nessa tecnologia do poder sobre a população é um poder contínuo, científico, "le pouvoir de "faire vivre"' (Foucault, 1997:220).

Foucault destaca a sexualidade como campo privilegiado para a operação dessa biopolítica - porque a sexualidade diz respeito, por um lado, ao corpo individual, mas por outro (em termos de procriação), se refere à população. Assim, situa-se ao mesmo tempo no eixo do organismo, corpo individual, e no eixo da população, fenômeno geral. Neste sentido, a investigação que realiza sobre a história da sexualidade é uma investigação sobre a biopolítica moderna. 
O último texto publicado em Dits et Écrits esclarece mais ainda esses conceitos:

\begin{abstract}
Nous pouvons dire, désormais, qu'à la fin du XVIII ${ }^{e}$ siècle la population devient le véritable objet de la police; ou, en d'autres termes, l'État doit avant tout veiller sur les hommes en tant que population. Il exerce son pouvoir sur les êtres vivants en tant qu'êtres vivants, et sa politique est, en conséquence, nécessairement une biopolitique. La population n'étant jamais que ce sur quoi veille l'État dans son propre intérêt, bien entendu, l'État peut, au besoin, la massacrer. La thanatopolitique est ainsi l'envers de la biopolitique. (Foucault, 1994:826)
\end{abstract}

Foucault trata, portanto, de poder: disciplinar e de controle (biopolítico). $\mathrm{Na}$ sua formulação, disciplina e controle são tecnologias do poder.

\title{
Perspectiva de Transformação, Resistência
}

Como todos os sistemas históricos, o capitalismo comporta contradições que, quando se agudizam, "the system reaches a point of bifurcation" (Wallerstein, 1999:74). Wallerstein acredita que há muitos indícios de que estamos hoje num ponto como este.

Mesmo admitindo a eficácia ainda maior da dominação ideológica através da ação cada vez mais contínua e contígua do sistema dos AIE, Althusser pensa que a dominação também produz resistência. Negri tem razão nesse ponto, quando percebe uma aproximação de Althusser com seu aluno e amigo Foucault. Mas existe entre eles uma diferença importante, em Althusser a resistência se vincula à luta de classes. Afirma Althusser: "Si les AIE ont pour fonction d'inculquer l'idéologie dominante, c'est qu'il y a résistance, s'il y a résistance, c'est qu'il y a lutte, et cette lutte est en définitive l'écho direct ou indirect, parfois proche ou le plus souvent lointain de la lutte des classes" (Althusser, 1995b:255).

O primeiro Althusser assumia o ponto de vista da reprodução e pensava a ideologia e sua eficácia apenas enquanto ideologia dominante. A perspectiva do dominado e da transformação estava ausente, o dominado só aparecia como assujeitado, subjugado. O último Althusser, porém, passa a admitir que a ideologia dominante é sempre incompleta, histórica, contraditória, parte das lutas de classe. Fala em sistema sempre contraditório das ideologias: "L'idéologie dominante n'est jamais en effet un fait accompli de la lutte de classe qui échappérait à la lutte de classe" (Althusser 1995b:254). 
Althusser diz que uma ideologia se torna dominante quando, com ela, a classe no poder consegue unificar-se e impor essa ideologia às massas exploradas como sendo ideologia delas. Diz, no entanto, que "cet état de choses, qui n'est jamais atteint, sauf périodes exceptionnelles, que tendanciellement dans l'histoire, suppose ce qui, contrairement à ce qu'on croit, ne va nullement de soi, à savoir, l'existence d'une idéologie dominante" (Althusser, 1994a,III:166). Quanto aos AIE, somente no Anexo do famoso artigo publicado em 1970 Althusser admitia a necessidade de incluir na análise as classes e a luta de classes. Já no texto de 1976, afirma que "les appareils idéologiques d’État sont nécessairement le siège et l'enjeu d'une lutte de classe, qui prolonge, dans les appareils de l'idéologie dominante, la lutte de classe générale qui domine la formation sociale" (Althusser, 1995b:255). Passa a incluir os dominados sob outra perspectiva que não exclusivamente a de assujeitados.

Como é possível que se formem resistências sob uma lógica de dominação total da sociedade? Onde essas resistências se tornam possíveis? Althusser fala em resistência e fala também em interstícios onde há ausência de relações mercantis:

Je soutenais alors l'idée que les 'îlots de communisme' existent dès aujourd'hui, dans les 'interstices' de notre société (interstices, mot que Marx appliquait (...) aux premiers noyaux marchands dans le monde antique), là où ne règnent pas des rapports marchands. Je crois en effet - et pense sur ce point être dans la ligne de la pensée de Marx - que la seule définition possible du communisme - s'il doit un jour exister dans le monde -, c'est l'absence de rapports marchands, donc de rapports d'exploitation de classe et de domination d'État. (Althusser, 1992:217; cf. também Althusser, 1998:285).

Por sua vez, Hardt e Negri pretendem, com o conceito de multidão, dar conta da 'nova realidade do capitalismo' e sobre essa nova realidade propõem, ou, nas suas próprias palavras, repropõem "o projeto político da luta de classes lançado por Marx” (Hardt \& Negri, 2005b:146). Assim, para além das diferenças, restrições e exclusões, a multidão abrange todos os que trabalham sob o domínio do capital e que potencialmente recusam esse domínio. Esse parece ser o projeto político para o qual tende a sua análise.

Para Hardt e Negri, "a multidão é um conceito de classe” e "a classe é determinada pela luta de classes” (Hardt \& Negri, 2005b:143,144). Argumentam que "as classes que importam são definidas pelo lineamento da luta coleti- 
va" e concluem: "a classe é um conceito político, em suma, na medida em que uma classe é e só pode ser uma coletividade que luta em comum" (Hardt \& Negri, 2005b:144). Assim, definem classe como sendo "efetivamente um conceito biopolítico" (Hardt \& Negri, 2005b:145). Por outro lado, Negri também entende multidão como "uma multiplicidade de singularidades que não pode encontrar unidade representativa em nenhum sentido". Diz que "os homens são singularidades, uma multidão de singularidades” (Negri, 2003:43).

Hardt e Negri encaminham cada vez mais claramente uma proposta de transformação por meio do que chamam 'multidão'. No diálogo com Danilo Zolo sobre Império, à pergunta sobre se eles pensam em uma transformação do mundo não somente política, mas também ética e cultural, Negri responde que eles vêem a revolução em termos éticos, políticos e de metamorfose biopolítica, "contra todas as estruturas centrais e periféricas do poder, para esvaziá-las e para subtrair ao capital a capacidade produtiva" (Negri, 2003:42). Apontam a possibilidade de construção de uma organização política alternativa ao Império, pela multidão. Dizem eles:

O Império com o qual nos defrontamos exerce enormes poderes de opressão e destruição, mas (...) oferece novas possibilidades para as forças de libertação. (...) As forças criadoras da multidão que sustenta o Império são capazes também de construir, independentemente, um Contra-Império, uma organização política alternativa de fluxos e intercâmbios globais. (Hardt \& Negri, 2005a:15)

Para eles, na realidade essa luta já começou.

Essa perspectiva de luta conduzida pela 'multidão' e pelos movimentos globais está presente em toda a produção recente de Hardt e Negri, explícita no que chamam de "projeto da multidão" (Hardt \& Negri, 2005b) e na perspectiva "da transformação e da possibilidade de uma nova ordem de valores e instituições, radicalmente democráticos” (Negri \& Cocco, 2005:15), que propõem. 
No capitalismo dependente, as relações que fundamentam a organização capitalista da sociedade são superdimensionadas e, portanto, se apresentam mais cruamente: a exploração é superexploração, a organização política oscila entre autocracia e ditadura, a concentração da renda e da propriedade é extremada (concentrando a riqueza, o poder e a cultura e ampliando exacerbadamente a polarização social), a dominação ideológica é maciça.

Uma sociedade assim constituída precisa construir o 'consenso' ininterruptamente, para o que mantém a informação sob controle estrito e bloqueia o acesso ao conhecimento e o confronto reflexivo e analítico entre possíveis formulações divergentes. Desqualifica-se a priori toda divergência e todo aquele que se opõe.

Portanto, para qualquer transformação mais profunda ou de maior fôlego nesta sociedade, a luta ideológica assume importância decisiva. Esse tipo de luta não prescinde do acesso mais geral possível ao conhecimento crítico e à sua análise e discussão.

Não se ultrapassa o 'consenso'/consentimento/submissão, que é construído ideologicamente pelo poder, sem questionar os quadros de pensamento estabelecidos e permanentemente reiterados pelas ideologias dominantes - que atuam como filtro do conhecimento e mesmo das informações e da percepção da realidade - e sem abrir espaços críticos de reflexão, que supõem elevação cultural geral.

Os movimentos de resistência ou de lutas se dão conta na sua prática dessas necessidades, tanto mais quanto mais pretendam ser autônomos frente às formas de poder e construir-se como espaços sociais alternativos - espaços de crítica e de democracia radical, onde não reinem relações mercantis.

\section{NOTAS}

${ }^{1}$ Jameson cita Ernst Mandel (Late Capitalism, 1978), que apresenta o capitalismo tardio como um terceiro momento na evolução do capital, que seria o mais puro estágio do capitalismo, mais do que qualquer dos seus momentos anteriores.

${ }^{2}$ Itálicos meus. Não havendo esse tipo de indicação, os itálicos das citações são dos originais.

3 “'Contemporary ancestors' or, conversely, 'primitive contemporaries"' (Latham, 2000:64).

4 "Even as the world became formally decolonized, modernizers continue to define the virtues of the 'advanced' nations in opposition to the intrinsic 'deficiencies' of the poorer 
ones, argued that contact with the West could only produce a beneficial, catalytic effort on 'backward' societies, and asserted that promoting global 'development' involved finding the right lessons in America's own historic past. Modernization theory resonated with previous combination of missionary vision and imperial control" (Latham, 2000:59-60).

${ }^{5}$ Para algumas das minhas análises sobre o capitalismo dependente em Florestan Fernandes, ver Cardoso (1996, 2005a).

${ }^{6}$ De fato, Max Weber faz a seguinte análise: “The capitalism of the middle ages began to be directed toward market opportunities (...) after the cities have lost their freedom. (...) Everywhere the military, judicial, and industrial authority was taken away from the cities. In form the old rights were as a rule unchanged, but in fact the modern city was deprived of its freedom as effectively as had happened in antiquity with the establishment of the Roman dominion, though in contrast with antiquity they came under the power of competing national states in a condition of perpetual struggle for power in peace or war. This competitive struggle created the largest opportunities for modern western capitalism. The separate states had to compete for mobile capital, which dictated to them the conditions under which it would assist them to power. Out of this alliance of the state with capital, dictated by necessity, arose the national citizen class, the bourgeoisie in the modern sense of the word. Hence is the closed national state which afforded to capitalism its chance for development - and as long as the national state does not give place to a world empire capitalism also will endure" (Weber, 1950:335, 337).

7 “...la marcha ulterior de la expropiación de los propietarios privados cobra una forma nueva. Ahora, ya no se trata de expropiar al trabajador independiente, sino de expropiar al capitalista explotador de numerosos trabajadores. Esta expropiación la lleva a cabo el juego de las leyes inmanentes de la propia producción capitalista, la centralización de los capitales. Cada capitalista desplaza a otros muchos. Paralelamente con esta centralización del capital o expropiación de muchos capitalistas por unos pocos ...” (Marx, 2000:648).

8 “....au sein du processus de la production, ce sont des agents qui en personnifient les facteurs, le capitaliste comme 'capital', le producteur immédiat comme 'travail', et leur rapport est déteminé par le travail, simple facteur du capital qui se valorise lui-même" (Marx, 1968:366).

${ }^{9}$ Deve-se considerar, no entanto, a observação de François Matheron, de que a relação dos últimos escritos com o conjunto da obra de Althusser não é simples, porque certamente há rupturas, mas também é possível descobrir nas suas notas de trabalho de 1966 "des remarques qui seront presque littéralement reprises dans ses derniers écrits: (...) Théorie de la rencontre (...)" (Althusser, 1994b:21).

${ }^{10}$ Para uma discussão que considera esta hipótese e se detém na produção do último Althusser, consultar Cardoso (2002).

${ }^{11}$ Adotando uma periodização indicada por Yves Sintomer (Althusser, 1998:8-9). 
12 "Je crois que c'est de cette conception juridique du pouvoir, de cette conception du pouvoir à partir de la loi et du souverain, à partir de la règle et de la prohibition qu'il faut maintenant se débarasser si nous voulons procéder à une analyse non plus de la représentation du pouvoir, mais du fonctionnement réel du pouvoir” (Foucault, 1994:186).

\section{REFERÊNCIAS BIBLIOGRÁFICAS}

ALTHUSSER, L. (em colaboração com É. Balibar, R. Establet, P. Macherey e J. Rancière). Lire Le Capital (Coleção "Théorie”), 2v. Paris: Maspero, 1965.

ALTHUSSER, L. L'Avenir Dure Longtemps. Paris: Stock, Imec, 1992.

ALTHUSSER, L. Sur la Philosophie. Paris: Gallimard, 1994a. I: Philosophie et marxisme: entretiens avec Fernanda Navarro (1984-1987), p.13-79; II : Correspondance (1984-1987), p.81-137; III: La transformation de la philosophie - Conférence de Grenade (1976), p.139-178.

ALTHUSSER, L. Écrits Philosophiques et Politiques. t. I. Textos reunidos e apresentados por François Matheron. Paris: Stock, Imec, 1994b. Présentation par François Matheron, p. 7-22 ; III: Le courant souterrain du matérialisme de la rencontre (1982), p.539-579.

ALTHUSSER, Lo. Écrits Philosophiques et Politiques. t. II. Textos reunidos e apresentados por François Matheron. Paris: Stock, Imec, 1995a. Machiavel et nous (1972-1986), p.39-168.

ALTHUSSER, L. Sur la Reproduction. Introdução de Jacques Bidet. Paris: PUF, 1995b. Note sur les AIE (1976), p.253-267; Idéologie et Appareils Idéologiques d'État (1970), p.269-314.

ALTHUSSER, L. Solitude de Machiavel. Edição preparada e comentada por Yves Sintomer. Paris: PUF, 1998. 8: Soutenance d'Amiens (1975), p.199-236; 11: Enfin la crise du marxisme! (1977), intervenção no Colóquio de Veneza, nov. 1977, p.267-280; 12: Le marxisme comme théorie 'finie' (1978), p.281-296; 13: Le marxisme aujourd'hui (1978), p.297-310.

ARRIGHI, G. O Longo Século XX: dinheiro, poder e as origens de nosso tempo. Rio de Janeiro, São Paulo: Contraponto, Unesp, 1996.

BALIBAR, É. Tais-toi encore, Althusser (1988). In: BALIBAR, É. Écrits pour Althusser. Paris: La Découverte, 1991.

BAUMAN, Z. Modernidade e Ambivalência. Rio de Janeiro: Zahar, 1999.

BENJAMIN, Wa. Sur le concept d'histoire. In: BENJAMIN, W. CEuvres, Tome III. Traduzido do alemão por Maurice de Gandillac, Rainer Rochlitz e Pierre Rusch. Paris: Gallimard, 2000. p.427-443.

BOURDIEU, P. Ce que Parler Veut Dire. Paris: Fayard, 1982. 
CALLINICOS, A. Against Postmodernism: a marxist critique. Cambridge: Polity Press, 1989.

CARDOSO, M. L. Ideologia do Desenvolvimento - Brasil: JK - JQ, 1972. Tese de Doutorado, São Paulo: Faculdade de Filosofia Letras e Ciências Humanas, Universidade de São Paulo. Publicada sob o título Ideologia do Desenvolvimento - Brasil: JK - JQ. Prefácio de Florestan Fernandes. 2.ed. Rio de Janeiro: Paz e Terra, 1978.

CARDOSO, M. L. Florestan Fernandes: a criação de uma problemática. Estudos Avançados, 10(26):89-128, 1996.

CARDOSO, M. L. Ideologia da globalização e (des)caminhos da ciência social. In: GENTILI, Pablo (Org.). Globalização Excludente: desigualdade, exclusão e democracia na nova ordem mundial. Petrópolis: Vozes, 1999. p.96-127.

CARDOSO, M. L. Sobre Althusser e a crise do marxismo. In: BOITO JR., A. et al. (Orgs.). A Obra Teórica de Marx: atualidade, problemas e interpretações. 2.ed. São Paulo: Xamã, 2002. p.107-121.

CARDOSO, M. L. Sobre a teorização do capitalismo dependente em Florestan Fernandes. In: FÁVERO, O. (Org.). Democracia e Educação em Florestan Fernandes. Campinas Niterói: Autores Associados, EdUFF, 2005a. p.7-40.

CARDOSO, M. L. Teorias da modernização e expansão capitalista. In: XII CONGRESSO BRASILEIRO DE SOCIOLOGIA, 31 de maio a 3 de junho de 2005, Belo Horizonte, Sociedade Brasileira de Sociologia, 2005b.

CARDOSO, M. L. Construindo o mundo do pós-guerra: a teoria da modernização. In: XXV CONGRESSO DA ASOCIACIÓN LATINOAMERICANA DE SOCIOLOGÍA (Alas), 22 a 26 de agosto de 2005, Porto Alegre, 2005c.

CÉSAIRE, A. Discours sur le Colonialisme. 1955. Paris \& Dakar: Présence Africaine, 1995.

CHESNAIS, F. A globalização e o curso do capitalismo de fim-de-século. Economia e Sociedade, 5, dez.1995.

CHESNAIS, F. A 'nova economia': uma conjuntura própria à potência econômica estadunidense. In: CHESNAIS, F. et al. Uma Nova Fase do Capitalismo? São Paulo: Xamã, Cemarx (IFCH-Unicamp), 2003.

DICKSON, A. K. Development and International Relations: a critical introduction. Malden: Polity Press \& Blackwell, 1997.

FERNANDES, Florestan. Sociedade de Classes e Subdesenvolvimento. Rio de Janeiro: Zahar, 1968. Cap. I: Sociedade de classes e subdesenvolvimento.

FERNANDES, F. Capitalismo Dependente e Classes Sociais na América Latina. Rio de Janeiro: Zahar, 1973. Cap. II: Classes sociais na América Latina. 
FERNANDES, F. A Revolução Burguesa no Brasil: ensaio de interpretação sociológica. Rio de Janeiro: Zahar, 1974.

FERNANDES, F. Brasil: em compasso de espera. São Paulo: Hucitec, 1980. Cap. 6: Um ensaio de interpretação sociológica. p.75-83.

FERNANDES, F. Nova República? Rio de Janeiro: Zahar, 1985.

FERNANDES, F. Em Busca do Socialismo: últimos escritos e outros textos. São Paulo: Xamã, 1995. Parte do capítulo 2: Capitalismo dependente e imperialismo.

FOUCAULT, M. Dits et Écrits. Paris: Gallimard, 1994. t. 4: Est-il donc important de penser? (Entretien avec Didier Éribon, 1981), p.178-182; Les mailles du pouvoir (1976), p.182-201; La technologie politique des individus (1982), p.813-828.

FOUCAULT, M. Il Faut Défendre la Société. Cours au Collège de France, 1976. Paris: Seuil/Gallimard, 1997.

GILMAN, N. Mandarins of the Future: modernization theory in Cold War America. Baltimore \& Londres: The Johns Hopkins University Press, 2003.

HABERMAS, J. The Philosophical Discourse of Modernity: twelve lectures. Cambridge: MIT Press, 1987.

HARDT, M. \& NEGRI, A. Império. Rio de Janeiro: Record, 2005a.

HARDT, M. \& NEGRI, A. Multidão. Rio de Janeiro: Record, 2005b.

HOBSBAWM, E. A Era dos Extremos: o breve século XX - 1914-1991. São Paulo: Companhia das Letras, 1997.

HORKHEIMER, M. \& ADORNO, T. W. Dialética do Esclarecimento. Rio de Janeiro: Zahar, 1985.

JAMESON, F. Postmodernism, or, The Cultural Logic of Late Capitalism. Durham: Duke University Press, 1991.

JAMESON, F. A Singular Modernity: essays on the ontology of the present. Londres e Nova York: Verso, 2002.

KELLEY, R. D. G. Freedom Dreams: the black radical imagination. Boston: Beacon Press, 2002.

KIELEY, R. Sociology \& Development: the impasse and beyond. Londres: UCL Press, 1995.

LATHAM, M. E. Modernization as Ideology: American social science and 'nation building' in the Kennedy era. Chapel Hill, Londres: The University of North Carolina Press, 2000.

MANDEL, E. Late Capitalism. Londres: Verso, 1978.

MARX, K. Introduction de 1857: contribution à la critique de l'économie politique. Paris: Éditions Sociales, 1957. 
MARX, K. Le Manifeste communiste (1848). Trad. M. Rubel e L. Évrard. In Karl Marx. Euvres: économie, I. Prefácio de François Perroux. Edição estabelecida e anotada por Maximilien Rubel. Paris: Gallimard (Bibliothèque de la Pléiade), 1965, p. 157-195.

MARX, K. Euvres: économie, II. Edição preparada e anotada por Maximilien Rubel. Paris: Gallimard (Bibliothèque de la Pléiade), 1968. Matériaux pour l'Économie' (1861-1865). I. Subordination formelle et réelle du travail au capital.

MARX, K. El Capital: crítica de la economía política. 3.ed, $1^{a}$ reimpressão. México: Fondo de Cultura Económica, 2000.

MEZZADRA, S. \& RAHOLA, F. The postcolonial condition: a few notes on the quality of historical time in the global present. Postcolonial Text, 2(1). Disponível em <htpp://www.pkp.ubc.ca/pocol/viewarticle>. Acesso em: 8 jan. 2006.

NEGRI, T. Pour Althusser: notes sur l'évolution de la pensée du dernier Althusser. In: ALTHUSSER, L. et al. Sur Althusser: passages. Paris: L'Harmattan, 1993.

NEGRI, A. Cinco Lições sobre Império. Com contribuições de Michael Hardt e Danilo Zolo. Rio de Janeiro: DP\&A, 2003.

NEGRI, A. \& COCCO, G. Glob(AL): biopoder e lutas em uma América Latina globalizada. Rio de Janeiro: Record, 2005.

PARSONS, T. Structure and Process in Modern Societies. Glencoe: The Free Press, 1960. cap.III.

THERBORN, G. 'Modernization': discourses, their limitations and their alternatives. In: SCHELKE, W. et al. Paradigms of Social Change: modernization, development, transformation, evolution. Frankfurt, New York: Campus Verlag, St. Martin Press, 2001. p.49-72.

WALLERSTEIN, I. The End of the World as We Know it: social science for the twenty-first century. Minneapolis, Londres: University of Minnesota Press, 1999.

WALLERSTEIN, I. Unthinking Social Science: the limits of the nineteenth-century paradigms. 2.ed. Com novo prefácio. Philadelphia: Temple University Press, 2001.

WEBER, M. General Economic History. Glencoe: The Free Press, 1950. 